\title{
Electro Physiological Test
}

\author{
Partha Haradhan Chowdhury*1 and Brinda Haren Shah ${ }^{2}$ \\ ${ }^{1}$ M.Optom, Associate Professor, Principal, Department of Optometry, Shree Satchandi Jankalyan Samiti Netra Prasikshan Sansthan, Pauri, Affiliated to \\ Uttarakhand State Medical Faculty, Dehradun, India
}

${ }^{2}$ M.Optom, Guest Lecturer, Department of Optometry, Shree Satchandi Jankalyan Samiti Netra Prasikshan Sansthan, Pauri, Affiliated to Uttarakhand, State Medical Faculty, Dehradun, India

Received: 䙵: October 26, 2018; Published: 啡: November 01, 2018

*Corresponding author: Partha Haradhan Chowdhury, M. Optom, Associate Professor, Principal, Department of Optometry, India

\section{Short Communication}

Electro physiological test consist of three test and they are:
a) Electro Retinogram
b) Electro Oculogram
c) Visual Evoked Potential

\section{Electro Retinogram}

Electro Retinogram records 'Retinal Action Potential' when Retina is stimulated by light. ERG have two electrodes.
a) Active Electrode
b) Reference Electrode

Active Electrode is placed on the cornea and Reference Electrode is placed on the forehead. Potential between two electrodes are Amplified and Displayed. Whatever the potential difference is being created that is between two cone cells and it is 1 mili volt only and it is called "Corneo Retinal Potential." At the posterior pole of eye, 1 mili volt potential difference is also created. This potential difference can be modified by changing the light stimulation on the Retina [1].

ERG consist of 3 waves.

i. "a wave"
ii. "b wave"

iii. "c wave"

a. a wave: It arises from the rod and cone cells and it is Corneo Negative

b. b wave: It arises from the "NULLER CELLS" and it is Corneo Positive.

c. c wave: It is a prolonged positive wave. It's a very time taking process.
Patient should be kept in a complete dark room up to 30 minutes before taking the 3 readings. Last two readings are taken after staying in diffuse bright light up to 10 minutes.

ERG is performed in cases of

i. Retinitis Pigmentosa

ii. Diabetic Retinopathy

iii. Central Retinal Artery Occlusion

Because in this case, abnormality is seen in the waves. Drug Retinal Toxicity is also diagnosed by ERG. ERG value is deteriorated in cases of Ptosis, Lens Opacity, Miosis, Inadequate Retinal Adaptation.

\section{Electro Oculogram}

Unlike ERG, EOG is being used in both light and dark conditions. In case of EOG, at first, two electrodes are used. 1st electrode is placed at the Lateral canthi and 2nd electrode is placed at the Medial canthi. Another electrode is placed at the Forehead. During the use of EOG, two lights are placed at side by side with thin 30 to $60 \mathrm{sec}$. and another light is placed just centrally of the patient. Patient is instructed to look that light Rhythmetically. EOG is only used when ERG is not available exceptionally in cases of Vitelliform Macular Degeneration. Here, ERG value is in normal condition but EOG value is reduced [2].

\section{Visual Evoked Potential}

It can record the "Electrical activity of the Visual Cortex" by the stimulation of the Retina. In case of VEP, the stimulus will be "Flash of light "on Black and White Checker Board. Here, latency or amplitude of VEP is recorded. The meaning of latency is "DELAY" Specifically, in case of babies, it is used to assess visual function. Optic Neuropathy Demyelinating disorder can also be diagnosed [3]. 


\section{References}

1. Brad Bowling (2016) Kanski's Clinical Ophthalmology E-Book: A Systematic Approach. In: Brad Bowling (Eds.) ( $8^{\text {th }}$ edn).

\section{ISSN: 2574-1241}

DOI: $10.26717 /$ BJSTR.2018.10.001991

Partha Haradhan Chowdhury. Biomed J Sci \& Tech Res

(C) (i) This work is licensed under Creative

Submission Link: https://biomedres.us/submit-manuscript.php
2. Sihota, Radhika Tandon (2018) Parson's Diseases of the Eye. In Sihota, Radhika Tandon (Eds.) (22 ${ }^{\text {nd }}$ Edn).

3. Samar K Basak (2009) Clinical Ophthalmology Atlas.

$\begin{array}{ll}\text { BIOMEDICAL } & \text { Assets of Publishing with us } \\ \text { RESEARCHES } & \text { - Global archiving of articles } \\ \text { - Immediate, unrestricted online access }\end{array}$

